\title{
Nicola Muschitiello, Un'estasi bolognese tra le pagine di Balzac
}

\section{Marco Stupazzoni}

\section{Q OpenEdition}

1 Journals

\section{Edizione digitale}

URL: http://journals.openedition.org/studifrancesi/36397

DOI: $10.4000 /$ studifrancesi.36397

ISSN: 2421-5856

\section{Editore}

Rosenberg \& Sellier

\section{Edizione cartacea}

Data di pubblicazione: 1 juillet 2005

ISSN: 0039-2944

\section{Notizia bibliografica digitale}

Marco Stupazzoni, «Nicola Muschitiello, Un'estasi bolognese tra le pagine di Balzac», Studi Francesi [Online], 145 (XLIX| I) | 2005, online dal 30 novembre 2015, consultato il 18 avril 2021. URL: http:// journals.openedition.org/studifrancesi/36397 ; DOl: https://doi.org/10.4000/studifrancesi.36397

Questo documento è stato generato automaticamente il 18 avril 2021.

\section{(c)}

Studi Francesi è distribuita con Licenza Creative Commons Attribuzione - Non commerciale - Non opere derivate 4.0 Internazionale. 


\title{
Nicola Muschitiello, Un'estasi bolognese tra le pagine di Balzac
}

\author{
Marco Stupazzoni
}

\section{NOTIZIA}

Nicola muschitiello, Un'estasi bolognese tra le pagine di Balzac, «Portici. Bimestrale della Provincia di Bologna», n 5, 2003, p. 45.

1 Nell'undicesima sala della Pinacoteca Nazionale di Bologna, è conservata la celebre Estasi di Santa Cecilia di Raffaello che Balzac ebbe occasione di contemplare durante il suo secondo viaggio in Italia nel 1837. Furono soprattutto la bellezza astratta e l'armonia musicale del capolavoro raffaelliano a colpire lo spirito e la sensibilità artistica dello scrittore francese: questo quadro, scrive l'A., «simbolo della sacralità della musica e dell'estasi che dona, Balzac lo portò dentro di sé. Forse lo considerava una specie di spartito ideale e facilmente leggibile, che perfino uno come lui, sprovvisto di dottrina musicale, poteva leggere e godere». Una sublime sinfonia di colori e di linee pure che il romanziere non esito a trasfigurare in forma letteraria in due significative opere narrative quali Une Fille d'Eve e Massimilla Doni, pubblicate entrambe nell'agosto del 1839. 